\begin{tabular}{|} 
Ambiente \& Água - An Interdisciplinary Journal of Applied Science \\
ISSN 1980-993X - doi:10.4136/1980-993X \\
www.ambi-agua.net \\
E-mail: ambi.agua@gmail.com
\end{tabular}

\title{
Canonical analysis of climatic factors associated with the quality characteristics of drinking water of a city in São Paulo State
}

\author{
ARTICLES doi:10.4136/ambi-agua.2219
}

Received: 01 Dec. 2017; Accepted: 20 Nov. 2018

\author{
Sérgio Augusto Rodrigues ${ }^{*}{ }^{*}$; Paulo André de Oliveira ${ }^{2}$; \\ Ricardo Ghantous Cervi ${ }^{3}{ }^{(D}$; Lilian Cristina Trevizan ${ }^{4}{ }^{(D}$; Carlos Roberto Padovani ${ }^{5}$ \\ ${ }^{1}$ Universidade Estadual Paulista "Júlio de Mesquita Filho" (UNESP), Botucatu, SP, Brasil \\ Faculdade de Ciências Agronômicas (FCA). Departamento de Bioprocessos e Biotecnologia (DBB). \\ E-mail: sergio.rodrigues@unesp.br \\ ${ }^{2}$ Faculdade de Tecnologia de Botucatu (FATEC-BT) \\ Centro Estadual de Educação Tecnológica Paula Souza, Botucatu, SP, Brasil. E-mail: \\ paulo.oliveira108@fatec.sp.gov.br \\ ${ }^{3}$ Universidade Estadual Paulista "Júlio de Mesquita Filho" (UNESP), Itapeva, SP, Brasil \\ Departamento de Engenharia de Produção. E-mail: ricardo.cervi@unesp.br \\ ${ }^{4}$ Companhia de Saneamento Básico do Estado de São Paulo (SABESP), Botucatu, SP, Brasil \\ Divisão De Controle Sanitário Do Médio Tietê (RMOC). E-mail: 1felipe @ sabesp.com.br \\ ${ }^{5}$ Universidade Estadual Paulista "Júlio de Mesquita Filho" (UNESP), Botucatu, SP, Brasil \\ Instituto de Biociências (IBB). Departamento de Bioestatística. E-mail: bioestatistica.ibb@unesp.br \\ "Corresponding author
}

\begin{abstract}
Several factors may contribute to changes in monitoring parameters of drinking water quality, especially climatic characteristics. Behavioral studies of these characteristics are relevant to the rational and sustainable use of water resources and better monitoring of the quality of water available for the population. To assess the association between water quality and climate, this research explored physical-chemical and microbiological characteristics considered important for the monitoring of water quality, analyzed in casual samples collected daily from the distribution system of a city, and considered monthly data of climatic characteristics from 2007 to 2011 . The associations between these two sets of variables were assessed by the multivariate procedure of the canonical correlation analysis. The results indicate a positive correlation between the canonical variable formed by the linear combination of climatic variables and the canonical variable formed by the linear combination of water quality variables.
\end{abstract}

Keywords: canonical correlation, climatic variables, drinking water, multivariate statistics.

\section{Análise canônica de fatores climáticos associados às características de qualidade da água potável de um município do Estado de São Paulo}

\section{RESUMO}

Diversos fatores podem contribuir para alterações dos parâmetros de monitoramento da qualidade da água potável, em especial, as características climáticas. Estudos do comportamento destas características tornam-se relevantes para utilização racional e sustentável dos recursos hídricos e melhor monitoramento da qualidade da água disponibilizada 
à população. Para avaliar a associação entre qualidade da água e o clima, esta pesquisa envolveu características físico-químicas e microbiológicas, consideradas importantes para o monitoramento de sua qualidade, analisadas em amostras casuais coletadas diariamente em pontos da rede de distribuição de um município e dados mensais de características climáticas, no período de 2007 a 2011. As associações entres estes dois conjuntos de variáveis foram avaliadas pelo procedimento multivariado de análise de correlação canônica. Os resultados obtidos indicaram uma correlação positiva entre a variável canônica formada pela combinação linear das variáveis climáticas e a variável canônica formada pela combinação linear das variáveis de qualidade da água.

Palavras-chave: água de consumo, correlação canônica, estatística multivariada, variáveis climáticas.

\section{INTRODUCTION}

Brazil is a privileged country in terms of water resources. Approximately $13 \%$ of the world's freshwater availability is in Brazilian territory. However, this idea of abundance generated a culture of abuse. In addition, the supply of treated water is not uniform among Brazilian regions, presenting several contrasts, such as the percentage of households with treated water (Rodrigues and Batistela, 2013).

Since water is an essential resource for human activities, its inadequate use and degradation due to pollution, coupled with scarcity in some regions, justifies a growing interest in studies related to its quality, and how to use it in a rational and sustainable way.

For Souza et al. (2014), the required level of water quality depends on its use, with different needs for consumption by humans, agriculture, among others.

In the agricultural sector, climatic characteristics and availability of quality water are determinant for productivity, either between food crops or renewable energy production. In urban water supply, where water is a possible source of disease transmission, treatment plants are essential to ensure its potability, preventing contamination and the spread of diseases. For this, the monitoring of water quality must be carried out through periodic assessments of its characteristics throughout the distribution system.

Among the literature, studies assessing the quality of drinking water, physical-chemical and microbiological variables are analyzed before home storage (Freire, 2012; Oliveira et al., 2012). Studies associating water characteristics with cases of diarrhea (Queiroz et al., 2009), water consumption with socioeconomic and climatic variables (Silva et al., 2008b) and water quality with the use and occupation of the soil (Freire and Castro, 2014) are also observed. Assessing variables of surface water quality, climatic and hydrological, Prathumratana et al. (2008) highlight significant correlations between precipitation and several water characteristics.

Studies of climatic variables associated with physical-chemical and microbiological characteristics may contribute to the improvement of techniques for monitoring the quality of water distributed to the population. However, statistically analyzing these variables in an independent way can restrict the interpretation of the analyzed data set. In cases where there is a structure of simultaneous relationship between variables, using multivariate techniques constitutes the most appropriate alternative for exploratory or inferential analysis.

Based on it, the objective of this study was to analyze the simultaneous relationship of climatic variables and physical-chemical and microbiological characteristics of water in the distribution system of a city and to identify the climatic variables that contribute most to the quality of consumed drinking water. 


\section{MATERIAL AND METHODS}

The study used data related to the physical-chemical and microbiological characteristics of water, in addition to climatic variables observed from January 2007 to December 2011 within the urban area of Botucatu city, located in the south-central region of São Paulo State - latitude $-22.88^{\circ}$ and longitude $-48.44^{\circ}$ (Figure 1 ).

Among the monitoring procedures of water quality, residual chlorine (CRL, measured in $\left.m g L^{-1}\right), \mathrm{pH}$, turbidity (TURB, in $u T$ ), apparent color (AC in $U C$ ), fluorine (F, in $m g L^{-1}$ ), water temperature ( $\mathrm{T}$ in $o C$ ), heterotrophic bacteria-forming units (HET in CFU $m L^{-1}$ ) and total coliform occurrence (TCO) are analyzed daily by the company responsible for water collection, treatment and distribution.

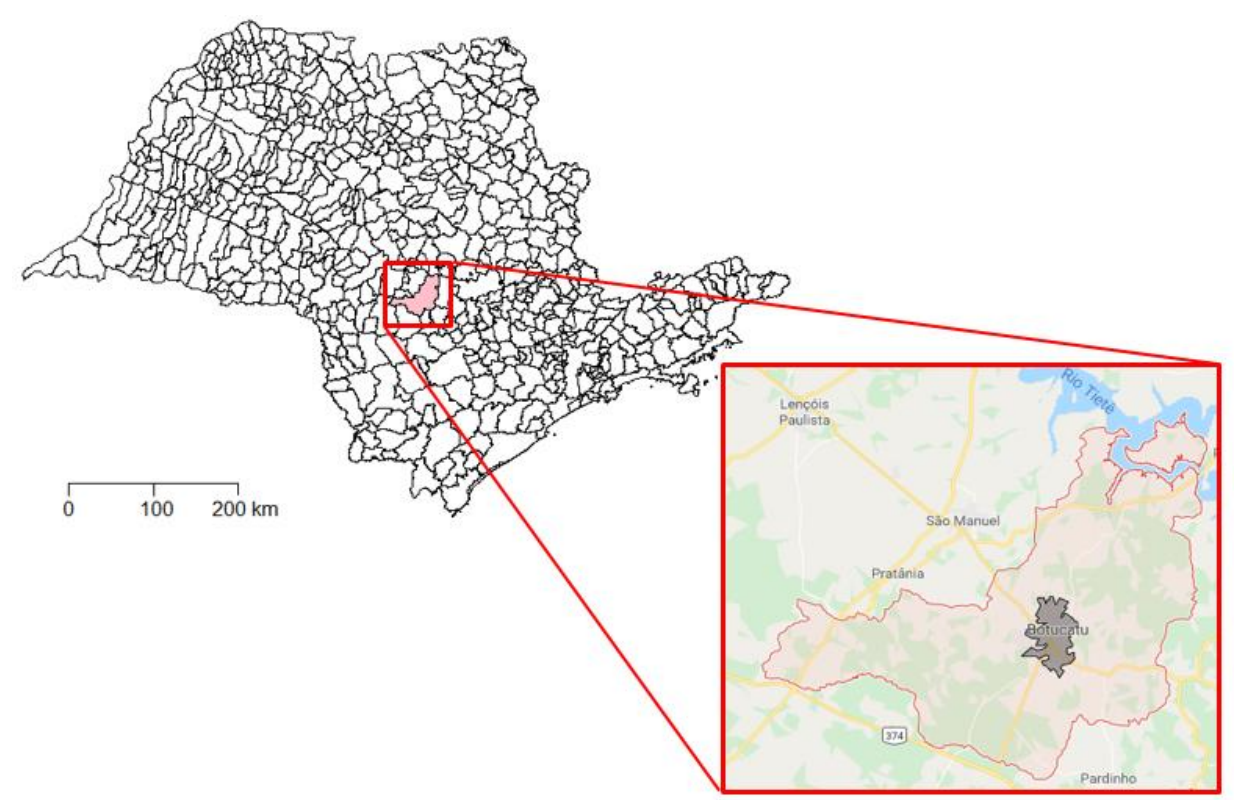

Figure 1. Location of the municipality and urban area of Botucatu, São Paulo State.

This study took into account the water-quality parameters established by Ordinance 518/04 (Brasil, 2011), besides the measurement of water temperature, which cannot be controlled, but should be monitored for possible actions to minimize the risk of bacterial presence (Oliveira et al., 2012).

The quantification of numerical values of the variables was carried out in the sanitary control laboratory of the basic sanitation company, based on casual daily water samples collected at several points within the city distribution system.

The daily data of climatic variables, minimum, maximum and mean monthly temperatures (TMIN, TMAX and TMEAN, all measured in $o C$ ), global solar radiation (RAD, in $\mathrm{cal} \mathrm{cm}^{-2} \mathrm{day}^{-}$ ${ }^{1}$ ), monthly rainfall (MR, in $\mathrm{mm}$ ), number of rainy days in the month (RD), relative air humidity (RH in \%), wind speed (WS, $\mathrm{km} \mathrm{h}^{-1}$ ), insolation (INSOL in hours) and evaporation (EV in $\mathrm{mm}$ ) were obtained from the weather station that provides climatic information to the assessed city.

In order to be compatible with the objective of the study, a database was organized consisting of the monthly averages of two sets of variables (eight variables characterizing water quality in the distribution system, and ten related to climatic characteristics), totaling 60 monthly averages, considered as random and independent sample units. The only exceptions are the total coliform occurrence (TCO) and rainy day (RD) frequency, which represent, respectively, the monthly proportion of samples with the absence of coliforms and the frequency of days with the presence of rain in the given month.

\section{IPABH}

Rev. Ambient. Água vol. 14 n. 1, e2219 - Taubaté 2019 
A statistical procedure of exploratory multivariate analysis was used to describe the associations between the two sets of variables, considering simultaneously all the variables and the entire structure of variation in the data; more precisely, the analysis of canonical correlation (Johnson and Wichern, 2007).

The canonical correlation analysis assesses the degree of association between two sets of random quantitative variables, summarizing the information of each set in linear combinations called canonical variables.

Thus, the random vector, represented by $X^{\prime}$ and composed of 18 variables as described above, is partitioned into two sets of variables: $X^{\prime(1)}$ - representing the random vector with 8 physical-chemical and microbiological variables of water; and $X^{\prime(2)}$ - the vector with 10 climatic variables. Thus, linear combinations of physical-chemical and microbiological variables of water can be obtained by $u t=a^{\prime} t X^{(1)}$ and of climatic variables by $v t=b^{\prime} t X^{(2)}$.

The coefficients $\left(a_{t}^{\prime}\right.$ and $\left.b_{t}^{\prime}\right)$ of $t$ pairs of canonical variables $\left(u_{t}, v_{t}\right)$, for $t$ varying from one to eight (the number of variables of the smallest set), are determined to maximize the correlation among the canonical variables in the set of linear combinations with variances equal to one, presenting all pairs $\left(u_{t}, v_{t}\right)$ and $\left(u_{t^{\prime}}, v_{t^{\prime}}\right)$ uncorrelated to each other, for $t \neq t^{\prime}$. The canonical correlation coefficient $\left(r_{u_{t}, v_{t}}\right)$, consists of the simple linear correlation, in absolute value, among the canonical variables. These correlations are determined in decreasing order of magnitude, i.e., the first pair of canonical variables $\left(u_{1}, v_{1}\right)$ is the one with the highest correlation and so on (Johnson and Wichern, 2007).

To verify if the found canonical correlations were significant, the statistical procedure was used, based on the likelihood ratio test with the correction proposed by Bartlett (Johnson and Wichern, 2007).

Some assumptions are necessary for generalizations of the results of canonical correlation analysis. Although it is not necessary, one of the assumptions for the method to perform better is that the response vector $x_{j}^{\prime}=\left(x_{j}^{\prime(1)} x_{j}^{\prime(2)}\right)$, for $j=1, \ldots n_{i}$, is a random sample of a population with normal multivariate distribution, which was verified by the Multivariate QQ Plot (Johnson and Wichern, 2007).

In order to assist in the interpretation of canonical variables and to improve the information quality of the analysis results, a correlation was established between the canonical variables and the original variables. The correlation between the canonical variables and the original variables of their respective sets, known as canonical charges, are given by $R_{u_{t}, X^{(1)}}=R^{(1,1)} a_{t}$ and $R_{v_{t}, X^{(2)}}=R^{(2,2)} b_{t}$, where $R^{(1,1)}$ and $R^{(2,2)}$ are respectively, the matrices of estimated correlations of the random vectors $X^{\prime}(1)$ and $X^{\prime(2)}$.

The results were discussed at a 5\% level of significance, with the calculations obtained by using R-Gui free software (R CORE TEAM, 2015).

\section{RESULTS AND DISCUSSION}

Initially, a descriptive statistical analysis of the climatic data was performed, showing that the period with the highest rainfall is concentrated between October and January. December and January had the most intense rainfall, with an average of $416.9 \mathrm{~mm}$ in January. On the other hand, the rains are very scarce between May and September, observing an average of five days with rain per month. August presented an average of $43.6 \mathrm{~mm}$ of precipitation. In addition, the city presented mild mean temperatures during all months of the year, with a minimum of $17.75^{\circ} \mathrm{C}$ in June, and a maximum of $23.60^{\circ} \mathrm{C}$ in February. It was also observed that the less rainy period corresponds to the colder months. 
Considering the water quality variables, few changes are noticed in the monthly mean of these variables in the city distribution system, indicating standard parameters of equivalent water quality throughout the months and meeting the drinking water analysis standards established by American Public Health Association (APHA et al., 2005).

Oliveira et al. (2012) also analyzed data on physical-chemical and microbiological variables, considering tap water samples before household storage, making sure that all parameters of water quality analyzed in the distribution system were within the standards established by the legislation. Freire (2012) analyzed samples from the treatment plant, the distribution system and the exit of the reservoirs, in order to assess the physical-chemical and microbiological variables of water distributed in Recife, Pernambuco state, verifying that household storage is a deteriorating factor of water quality.

Pinto and Maheshwari (2011) point out that some countries have been seeking to develop more efficient methodologies to evaluate water quality for human consumption and biotic species. They reported that the techniques of multivariate statistics are drawing attention, since they facilitate the understanding of the biological phenomenon, which, usually, involves datasets with many variables correlated with each other.

Regarding the study of joint association between the two sets of variables, at first by visual inspection of the multivariate probability QQ Plot ("Chi-Square plot"), with the exception of the two largest ordered distances, a trend of the others in aligning themselves around the bisector is noticed, suggesting, in practice, data adherence to the multivariate normal distribution of probability. In addition, the exploratory analysis indicated that the data of water characteristics are approximately symmetrical, an important condition for the robustness of the test in relation to non-normality (Mardia, 1974).

The canonical correlation coefficients, with their respective significance tests, are presented in Table 1. It can be seen that two, the first ones, out of eight canonical correlations found were significant $(\mathrm{p}<0.05)$, presenting values equal to 0.920 and 0.810 respectively. These results show evidence of an association between climatic characteristics and water quality.

Assessing the association between groundwater quality and land use in a city of Espírito Santo state, Menezes et al. (2014) identified a significant linear association between land use in the region and water quality through an exploratory study using canonical correlation.

Also in Table 1, it is possible to observe the coefficients of the canonical functions of each pair of variables and to identify that the canonical variable $u_{1}$ is associated with the water quality variables, in a contrast between the sum of apparent color (AC), fluoride (F) and water temperature (T) variables and the sum of turbidity (TURB), free residual chlorine (CRL), $\mathrm{pH}$, heterotrophic bacteria (HET) and total coliforms (TCO). The weights of each variable in this association are expressed in the coefficients of the canonical function, being the variables for $\mathrm{T}$ (0.641), CRL (-0.630), TURB (-0.514) and AC (0.433) with higher absolute weights. In the same way, the most expressive coefficients can be observed in the composition of the canonical function $v_{1}$.

Figure 2 shows the scatter diagrams of the standard values of the first (Figure 2A) and second (Figure 2B) pair of canonical variables.

Figure $2 \mathrm{~A}$ shows a positive linear association between the canonical variable $v_{1}$ (climatic component) and the variable $u_{1}$ (water quality component). In this sense, it can be said that the canonical variable $u_{1}$ presents high values associated with high values of the variable $v_{1}$, mainly in the months of June and July (winter), whereas low values for the two variables are observed between the months of November to March (hottest months of the year).

Figure 3 highlights the canonical charges of the first (Figure 3A and 3C) and second (Figure 3B and 3D) pair of canonical variables. The greater the absolute value of the canonical charge, indicated in the chart by the longer bar, the more important is the original variable to represent its respective canonical variable, that is, the greater the association of this variable

\section{IPABH}

Rev. Ambient. Água vol. 14 n. 1, e2219 - Taubaté 2019 
with the respective canonical variable (Johnson and Wichern, 2007).

Table 1. Coefficients of canonical functions, canonical correlation between water quality component $\left(u_{t}\right)$ and climatic $\left(v_{t}\right)$, eigenvalue, and result of the statistical test.

\begin{tabular}{|c|c|c|c|c|c|c|c|c|c|}
\hline \multirow[b]{2}{*}{$\begin{array}{l}\text { Canonical } \\
\text { Variables }\end{array}$} & \multirow[b]{2}{*}{$\begin{array}{c}\text { Original } \\
\text { variables }\end{array}$} & \multicolumn{8}{|c|}{ Coefficients of canonical functions } \\
\hline & & $\begin{array}{c}1^{\text {st }} \\
\left(u_{1} \cdot v_{1}\right)\end{array}$ & $\begin{array}{c}2^{\text {nd }} \\
\left(u_{2} \cdot v_{2}\right)\end{array}$ & $\begin{array}{c}3^{\text {rd }} \\
\left(u_{3} \cdot v_{3}\right)\end{array}$ & $\begin{array}{c}4^{\text {th }} \\
\left(u_{4} \cdot v_{4}\right)\end{array}$ & $\begin{array}{c}5^{\text {th }} \\
\left(u_{5} \cdot v_{5}\right)\end{array}$ & $\begin{array}{c}6^{\text {th }} \\
\left(u_{6} \cdot v_{6}\right)\end{array}$ & $\begin{array}{c}7^{\text {th }} \\
\left(u_{7} \cdot v_{7}\right)\end{array}$ & $\begin{array}{c}8^{\text {th }} \\
\left(u_{8} \cdot v_{8}\right)\end{array}$ \\
\hline \multirow{8}{*}{$\begin{array}{l}\text { water } \\
\text { quality } u_{t}\end{array}$} & TURB & 0.514 & -0.938 & 0.096 & -0.339 & 0.036 & -1.409 & -1.105 & 1.561 \\
\hline & $\mathrm{AC}$ & -0.433 & 0.602 & -0.366 & 0.165 & 0.242 & 0.607 & 0.834 & -2.068 \\
\hline & F & -0.038 & 0.268 & -0.015 & 0.909 & 0.002 & -0.680 & 0.766 & 0.276 \\
\hline & CRL & 0.630 & -0.342 & -0.231 & 0.959 & -1.013 & -0.519 & 0.790 & -0.173 \\
\hline & $\mathrm{pH}$ & 0.219 & 0.184 & 0.206 & -0.339 & -1.052 & 0.049 & 0.916 & -0.242 \\
\hline & $\mathrm{T}$ & -0.641 & -0.534 & -0.089 & 0.432 & -0.661 & -0.220 & -0.268 & 0.006 \\
\hline & HET & 0.137 & -0.578 & 0.430 & -0.161 & 0.686 & 0.288 & 0.335 & -0.026 \\
\hline & TCO & 0.041 & 0.140 & 0.846 & 0.127 & 0.007 & 0.038 & -0.487 & -0.314 \\
\hline \multirow{10}{*}{ climatic $v_{t}$} & $\mathrm{RD}$ & -0.242 & -0.148 & -1.523 & -0.678 & 0.097 & 0.701 & 0.320 & -0.859 \\
\hline & TMIN & -0.657 & -0.215 & 0.902 & -0.152 & -1.413 & 1.332 & -0.196 & -0.476 \\
\hline & TMAX & -0.241 & 0.246 & 0.595 & 0.280 & 0.323 & -0.205 & -1.876 & -0.404 \\
\hline & TMEAN & -0.030 & -0.420 & -0.587 & 0.085 & 0.418 & -1.595 & 1.400 & -0.069 \\
\hline & MR & 0.425 & -0.273 & 0.683 & 0.102 & 0.318 & -0.205 & -0.369 & 1.051 \\
\hline & RH & -0.301 & 0.800 & 0.182 & -0.241 & -0.289 & -0.247 & -0.383 & 0.528 \\
\hline & WS & -0.230 & 0.603 & 0.105 & 0.210 & 0.282 & 0.238 & -0.092 & -0.430 \\
\hline & EV & 0.433 & 0.384 & -1.452 & 0.329 & -0.433 & -0.190 & 0.221 & 1.027 \\
\hline & INSOL & 0.228 & -0.124 & -0.305 & -0.160 & -0.985 & 0.496 & -0.027 & -0.228 \\
\hline & RAD & -0.368 & -0.512 & 0.819 & 0.300 & 0.785 & 0.456 & 0.491 & 0.231 \\
\hline \multicolumn{2}{|c|}{$\begin{array}{l}\text { Canonical Correlation } \\
\left(r_{u_{t}} \cdot v_{t}\right)\end{array}$} & 0.920 & 0.810 & 0.604 & 0.524 & 77 & 0.360 & 0.302 & 0.092 \\
\hline \multirow{3}{*}{\multicolumn{2}{|c|}{$\begin{array}{l}\text { Eigenvalue } \\
\text { Test Statistics } \\
\text { df }\end{array}$}} & 0.847 & 0.656 & 0.364 & 0.275 & 0.227 & 0.130 & 0.090 & 0.009 \\
\hline & & 208.66 & 118.22 & 65.64 & 43.11 & 26.79 & 13.24 & 5.76 & 0.48 \\
\hline & & 80 & 63 & 48 & 35 & 24 & 15 & 8 & 3 \\
\hline \multicolumn{2}{|l|}{$\mathrm{p}$ value } & $<0.001$ & $<0.001$ & 0.05 & 0.160 & 0.310 & 0.580 & 0.670 & 0.920 \\
\hline
\end{tabular}

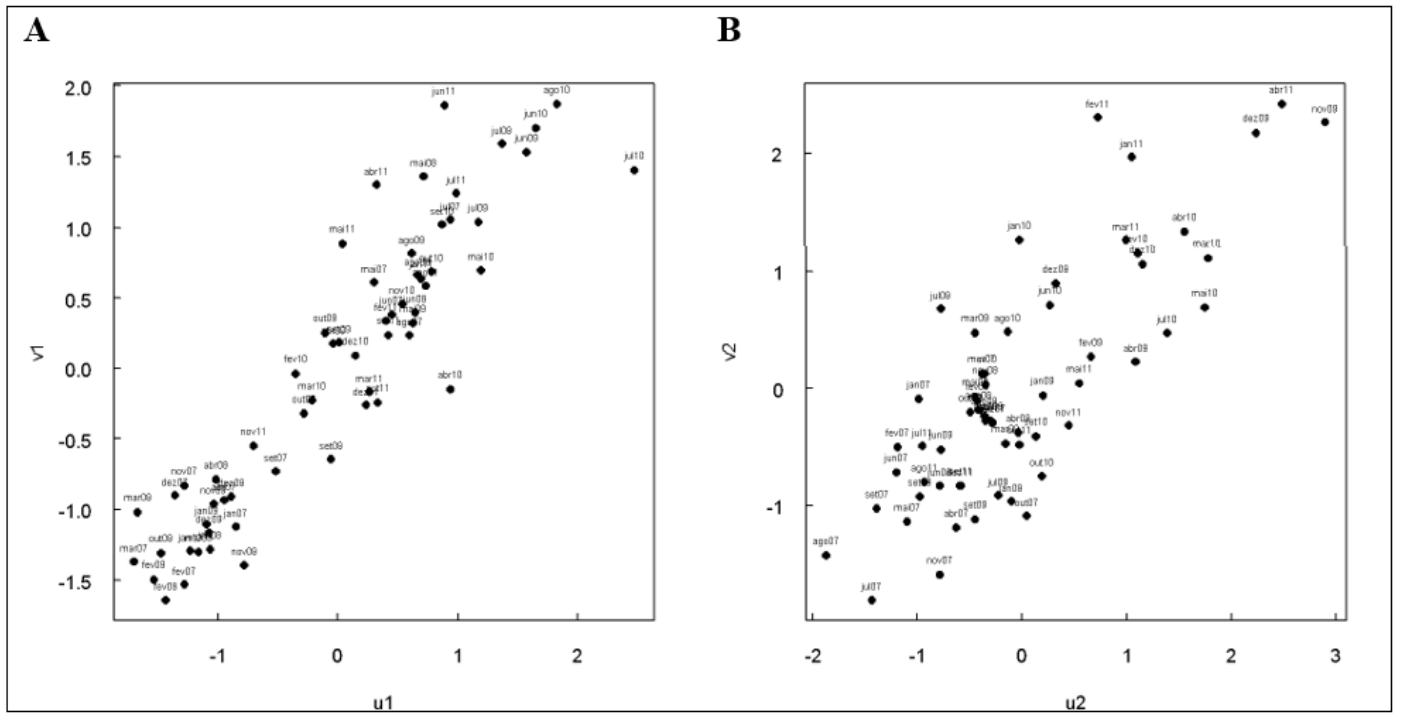

Figure 2. Scatter plot of the two pairs of standardized canonical variables.

Analyzing the canonical charges for the interpretation of $u_{1}$ (Figure $3 \mathrm{~A}$ ), the water quality variables that present higher charges (higher association with $u_{1}$ ) are water temperature $(-0.82)$ 
and chlorine (0.72), followed by fluorine (-0.47). The other variables presented low expressive canonical charges (below 0.4). It can be seen that higher concentrations of chlorine occur with lower water temperatures and concentrations of fluorine. This pattern suggests an interpretation for $u_{1}$ related to "water treatment chemicals".

Thus, it can be said that water temperature and free residual chlorine presented the highest percentages of variance explained by the first canonical variable of water quality $\left(u_{1}\right)$, i.e., $67 \%$ $\left(0,82^{2} \times 100\right)$ and $52.1 \%\left(0,72^{2} \times 100\right)$, respectively.

When observing the canonical charges of the climatic variables set (Figure 3C), the variables that have the highest correlations with $v_{1}$ are the minimum $(-0.82)$, mean $(-0.72)$, and maximum temperature $(-0.56)$, number of rainy days $(-0.57)$, and relative humidity $(-0.53)$. This pattern suggests $v_{1}$ interpreted as "moisture and temperature characteristics".

Thus, the first canonical variable of climatic characteristics $\left(v_{1}\right)$ explains $67 \%$ of the variability of the minimum temperature variable, $52 \%$ of the mean temperature and around $30 \%$ of the variability of rainy days, maximum temperature, and relative air humidity variables (canonical charges squared).

Therefore, based on the analysis of the canonical charges and the result presented in Figure $2 \mathrm{~A}$, we can say that June and July present high values for the two canonical variables, indicating a drier period and lower temperatures associated with a period in which the water distributed to the population had lower temperatures, less fluorine, and more chlorine. However, the months from November to March were shown to be a wetter period, with a higher number of rainy days and higher temperatures associated with months when water presented less chlorine, higher temperatures, and higher fluoride concentration (Figure 3).

A

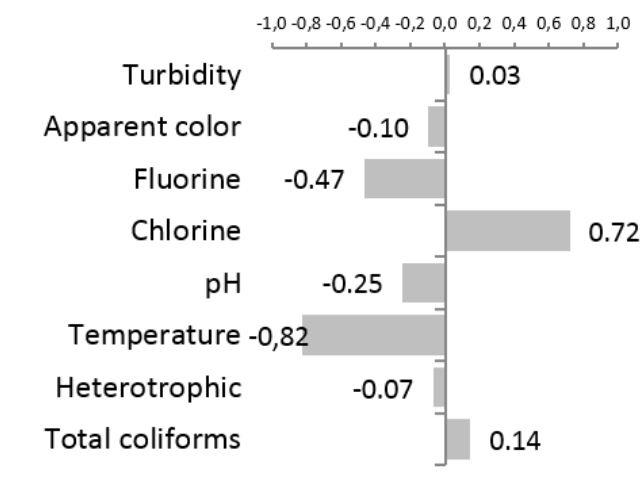

C

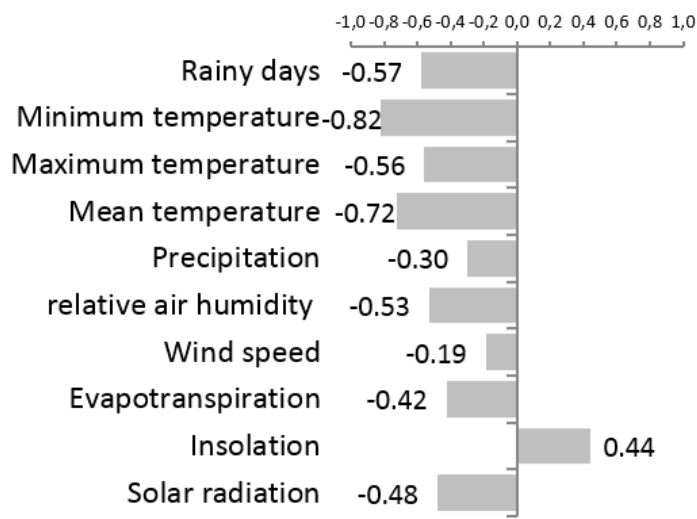

B

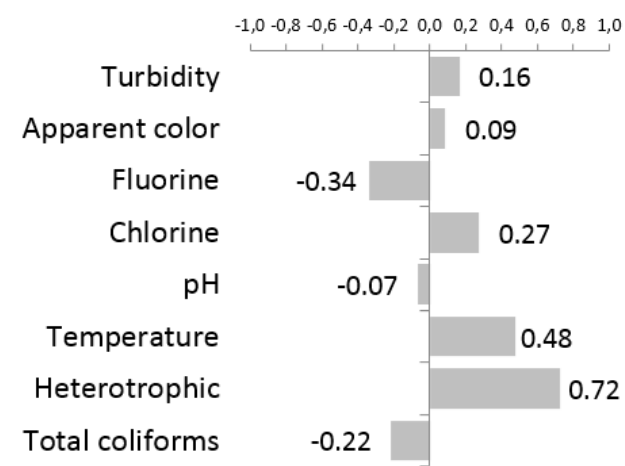

D

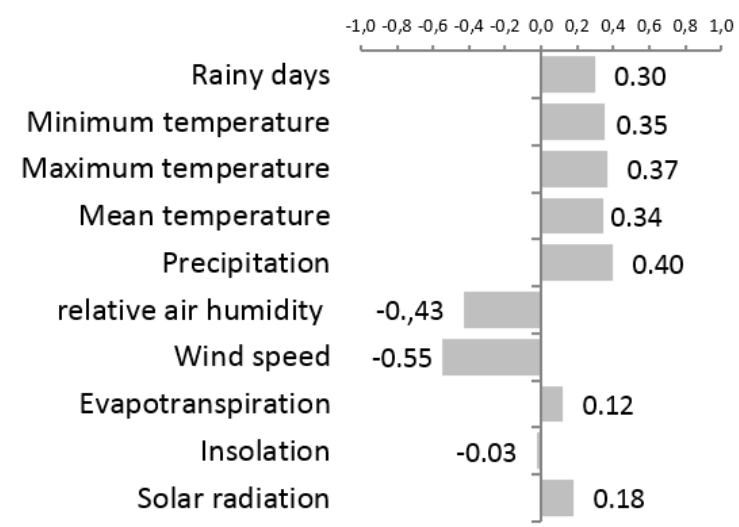

Figure 3. Canonical charges of the components: $u_{1}(\mathrm{~A}), u_{2}(\mathrm{~B}), v_{1}(\mathrm{C})$ and $v_{2}(\mathrm{D})$.

Nouri et al. (2015) observed significant differences in temperature, turbidity and chlorine concentration among water samples collected in the distribution system of a city in Iran in two seasons of the year (winter and spring), while $\mathrm{pH}$ was not different. It was also observed that

\section{IPABH}

Rev. Ambient. Água vol. 14 n. 1, e2219 - Taubaté 2019 
the water temperature showed a significant negative correlation only with free residual chlorine, a result similar to that observed in the water quality component of this study, evidencing the importance of this parameter of chlorine decay studies in drinking water distribution systems.

Assessing the interrelationships among precipitation, raw water quality and treatment, Santos and Sampaio (2009) verified that the precipitation was negatively associated with $\mathrm{pH}$ and turbidity, and positively with apparent color. They also observed that changes in water quality led to an increase in chlorine dosages at the water treatment plant during the wettest period.

In the process of water disinfection with chlorine, normally used in water treatment plants, it is possible to observe the formation of Trihalomethanes (THM), a carcinogenic chemical compound, and its formation is associated with several aspects, i.e., with the presence of organic material, with the treatment operating processes, and with geographic and climatic factors. A study carried out in a water distribution system in Scotland indicated significant positive correlations between THM concentration with dissolved organic carbon (DOC) and with the ambient temperature, while the chlorine concentration (free and total) was associated negatively with THM. Thus, in situations of higher ambient temperature, THM monitoring becomes essential, highlighting the importance of studies on the impact of global warming on water quality (Valdivia-Garcia et al., 2016).

Considering the second canonical pair (Figure 2B), some particularities of answers are highlighted in certain months and years. It was possible to verify that the months of November (2009), December (2009) and April (2011) presented high values in the two canonical variables, $u_{2}$ and $v_{2}$. In contrast, low values were found in July and August (2007). In January and February (2011), there were low values for the water quality component associated with high values of the climatic component.

Based on the canonical charges of this pair, it was observed that the canonical variable $u_{2}$ (representing another water characteristic), assumes higher values in the months in which water has less fluoride, higher chlorine concentration, higher temperatures and higher amount of heterotrophic bacteria (Figure 3B); while $v_{2}$ is higher in the months with higher precipitation, higher minimum, maximum and mean temperatures, low relative air humidity and low wind speed (Figure 3D).

Similarly, Freire and Castro (2014) used the canonical correlation technique to summarize the water quality in a component related to the concentration of nitrates and dissolved oxygen, verifying that a greater degradation of water quality in the watershed of Itapemirim River, Espírito Santo state, is associated with the use and occupation of the soil; more precisely, with the places with greater human activity. Bishankha et al. (2013) observed that bacterial growth in water treatment plants is strongly positively correlated with water temperature, evidencing the importance of monitoring free residual chlorine in times with higher temperatures.

Analyzing the differences between the dry period (June, July, August and October) and rainy period (December, January, February and April), concerning the behavior of the physicalchemical and biological variables analyzed in water samples from a dam that supplies tanks and nurseries for fish farming, Bufon and Landim (2007) verified that the values of phosphates and total phosphorus are directly related to the material suspended in water only during the dry period.

Regarding the influence of rainfall on the characteristics of raw water quality (Purus River, Amazonas state), Silva et al. (2008a) observed a negative correlation between precipitation and turbidity, and positive correlation between precipitation and temperature, conductivity, dissolved oxygen, total suspended solids, and $\mathrm{pH}$.

Thus, in general, the discussed results indicate that it is possible to summarize the information of variables related to water quality in the city distribution system and climatic

Rev. Ambient. Água vol. 14 n. 1, e2219 - Taubaté 2019 
variables in two pairs of components or canonical variables with significant correlations $\left(u_{1}\right.$, $\left.v_{1}\right)$ and $\left(u_{2}, v_{2}\right)$, each expressing a particular water quality and climatic characteristic.

As for this study limitation, the fact stands out that these results are restricted to the city described here, with the possibility of repetition in other localities, provided that a consistent data set is available.

\section{CONCLUSION}

The study pointed to the existence of two significant positive correlations between the set of water quality variables in the distribution system and the set of climatic variables.

In the context of the canonical charges, the water quality component is highlighted for fluorine, chlorine, and temperature; and for the climatic component, the frequency of rainy days, temperatures, relative air humidity, solar radiation and insolation. The months with high humidity, higher temperatures, higher levels of solar radiation and lower insolations are associated with months in which the water in the system presents with higher temperatures, higher concentrations of fluorine and lower concentrations of chlorine.

It is also observed that the months in which water presented with less fluorine, higher chlorine concentration, higher temperatures and higher amount of heterotrophic bacteria also presented with a higher precipitation, higher temperatures, lower relative air humidity and low wind speed.

In the warmer months and in months with higher precipitation, there is a need to increase the amount of chlorine in the water, as it is lost by evaporation at higher temperatures, becoming more susceptible to contamination by heterotrophic bacteria.

These conclusions confirm the current procedure of increasing chlorine in summer and emphasize the need for changes in chlorine concentrations according to ambient temperature and precipitation levels. Thus, the presented procedure can be used as a technique to assess the association of water characteristics with climatic factors in the various cities and sanitation companies.

\section{REFERENCES}

AMERICAN PUBLIC HEALTH ASSOCIATION (APHA); AMERICAN WATER WORKS ASSOCIATION (AWWA); WATER ENVIRONMENT FEDERATION (WEF). Standard methods: for the examination of water and wastewater. 21st. ed. Washington, DC, 2005.

BISHANKHA, S.; BHATTA, D. R.; JOSHI, D. R.; JOSHI, T. P. Assessment of microbial quality of chlorinated drinking tap water and susceptibility of gram negative bacterial isolates towards chlorine, Journal of Science, Engineering and Technology, v. 9, n. 1, p. 222-229, 2013. http://dx.doi.org/10.3126/njst.v13i1.7456

BRASIL. Ministério da Saúde. Portaria n 2.914, 14 de dezembro de 2011. Procedimentos de controle e de vigilância da qualidade da água para consumo humano e seu padrão de potabilidade. Diário Oficial [da] União, seção 1, Brasília, DF, n. 239, p. 39, 14 dez. 2011.

BUFON, A. G. M.; LANDIM, P. M. B. Análise da qualidade da água por metodologia estatística multivariada na Represa Velha (CEPTA/IBAMA/PIRASSUNUNGA/SP). Holos Environment, v. 7, n. 1, p. 42-59, 2007. http://dx.doi.org/10.14295/holos.v7i1.972

FREIRE, R. C. Qualidade da água nos reservatórios domiciliares na região metropolitana da cidade do Recife-PE. Journal of Management \& Primary Health Care, v. 3, n. 2, p. 102-105, 2012. 
FREIRE, A. P.; CASTRO, E. C. Análise da Correlação do uso e Ocupação do Solo e da Qualidade da Água, RBRH-Revista Brasileira de Recursos Hídricos, v. 19, n. 1, p. 41 49, 2014. http://dx.doi.org/10.21168/rbrh.v19n1.p41-49

JOHNSON, R. A.; WICHERN, D. W. Applied multivariate statistical analysis. 6. ed. New Jersey: Prentice-Hall, 2007. 800 p.

MARDIA, K. V. Assessment of multinormality and the robustness of Hotelling T2 test. Applied Statistics, v. 24, p. 163-171, 1974.

MENEZES, J. P. C.; BERTOSSI, A. P. A.; SANTOS, A. R.; NEVES, M. A. Correlação entre uso da terra e qualidade da água subterrânea. Engenharia Sanitária e Ambiental, v. 19, n. 2, p. 173-186, 2014. https://doi.org/10.1590/S1413-41522014000200008

NOURI, A.; SHAHMORADI, B.; DEHESTANI-ATHAR, S.; MALEKI, A. Effect of temperature on $\mathrm{pH}$, turbidity and residual free chlorine in Sanandaj water distribution network, Iran. Journal of advances in environmental health research, v. 3, n. 3, 2015. https://doi.org/10.22103/JAEHR.2015.40202

OLIVEIRA, A. S.; SANTOS, D. C.; OlIVEIRA, E. N. A.; BRITO, J. G.; SILVA, W. L. Qualidade da água para consumo humano distribuída pelo sistema de abastecimento público em Guarabira - PB. Revista Verde de Agroecologia e Desenvolvimento Sustentável, v. 7, n. 2, p. 199-205, 2012.

PINTO, U.; MAHESHWARI, B. L. River health assessment in peri-urban landscapes: na application of multivariate analysis to identify the key variables. Water Research, v. 45, p. 3915-3924, 2011. https://doi.org/10.1016/j.watres.2011.04.044

PRATHUMRATANA, L.; STHIANNOPKAO, S.; KIN K. W. The relationship of climatic and hydrological parameters to surface water quality in the lower Mekong River. Environment International, v. 34, p. 860-866, 2008. https://doi.org/10.1016/j.envint.2007.10.011

QUEIROZ, J. T. M.; HELLER, L.; SILVA, S. R. Análise da correlação de ocorrência de doença diarreia aguda com a qualidade da água para consumo humano no município de VitóriaES. Saúde Sociedade, v. 18, n. 3, p. 479-489, 2009. http://dx.doi.org/10.1590/S010412902009000300012

R CORE TEAM. R: A language and environment for statistical computing. Vienna: $R$ Foundation for Statistical Computing, 2015. Disponível em: http://cran.r-project.org/. Acesso em: 20 jan. 2015.

RODRIGUES, S. A.; BATISTELA, G. C. Uma revisão sobre a disponibilidade hídrica brasileira para geração de energia elétrica, Geoambiente on-line, n. 21, p. 48-67, 2013. https://doi.org/10.5216/revgeoamb.v0i21.27907

SANTOS, G. O.; SAMPAIO, G. M. S. Interrelações entre as chuvas, a qualidade da água bruta e o tratamento da água: Estudo de caso. Revista Tecnol, v. 30, n. 2, p. 163-174, 2009.

SILVA, A. E. P.; ANCELIS, C. F.; MACHADO, L. A. T.; WAICHAMAN, A. V. Influência da precipitação na qualidade da água do rio Purus. Acta Amazônica, v. 38, n. 4, p. 733742, 2008a. http://dx.doi.org/10.1590/S0044-59672008000400017

SILVA, W. T. P.; SILVA, L. M.; CHICHORRO, J. F. Gestão de recursos hídricos: perspectivas do consumo per capita de água em Cuiabá. Engenharia Sanitária e Ambiental, v. 13, n. 1, 2008b. http://dx.doi.org/10.1590/S1413-41522008000100002 
SOUZA, J. R.; MORAES, M. E. B.; SONODA, S. L.; SANTOS, H. C. R. G. A importância da qualidade da água e os seus múltiplos usos: caso do Rio Almada, sul da Bahia, Brasil. Revista eletrônica do Prodema, v. 8, n. 1, p. 26-45, 2014.

VALDIVIA-GARCIA, M.; WEIR, P.; FROGBROOK, Z.; GRAHAM, D. W.; WERNER, D. Climatic, geographic and operational determinants of trihalomethanes (THMs) in drinking water systems, Scientific Reports - Nature, v. 6, p. 35027, 2016. https://doi.org/10.1038/srep35027 